\title{
Internal Structure and Rheological Properties of Cosmetic and Toiletry Products
}

\author{
Yoshifumi YAMAGATA \\ Behavioral Science Research Institute, Lion Corporation, \\ 7-2-1 Hirai, Edogawa-ku, Tokyo 132-0035, Japan
}

\begin{abstract}
It is very important for product engineers in the field of cosmetics and toiletry industry to guarantee consumers to keep the constant quality and feeling of the products during the home use. This study aims at establishing technology for property control of toiletry products containing a long-chain alcohol and surfactants. Internal structure of cosmetic and toiletry products such as a self-assembly comprising cetyltrimethylammonium chloride (C16CA), cetyl alcohol $(\mathrm{C} 16 \mathrm{OH})$ and water was examined by electron microscopy et al. Rheological behaviors of the self-assembly were also observed to clarify the internal structure change during aging. It was confirmed that the self-assembly prepared at higher temperature involves multilamellar vesicles dispersed in continuous phase and also that semi translucent lamella was formed when self-assembly was prepared at room temperature. Phase transition of self-assembly from multilamellar vesicles to lamellae was confirmed on aging. Shear flow tests described showed that self-assembly is shear thinning with a hysteresis at higher shear rate and the maximum apparent viscosity made a steep and linear increase in a few days after preparation, followed by a gradual increase on further aging. Based on the creep test, a mechanical model for self-assembly was presented by 6 elements. The dependence of dynamic modulus $\left(G^{\prime}\right)$ and loss modulus $\left(G^{\prime \prime}\right)$ on frequency $(\omega)$ was obtained. The Cole-Cole plots were combination of 2 arcs, indicating coexistence of 2 different relaxation mechanisms. They are attributed to the formation of the networks of vesicles and of lamellae. The change in the relaxation mechanisms also corresponds to the phase transition in self-assembly. In conclusion, this study unveiled the internal structure of the self-assembly comprising surfactants as a main component and showed its close relation with rheological behaviors.
\end{abstract}

Key Words: Cetyl alcohol / Cetyltrimethylammonium chloride / Cole-Cole plot / Self-assembly / cohesive energy

\section{化粧品用基剤の内部構造とレオロジー}

\author{
山縣 義文
}

(原稿受理：2013 年 2 月 22 日)

\section{1. はじめに}

香粧品や化粧品は皮膚や毛髪に直接塗布するため, 生理 学的作用や安全性を十分に考慮しなければならないことは, 製品開発を行う上で当然のことである。

また，製品を使用する生活者の視点に立てば，人が五感 で感じる使用感や触感などの感性工学的な要素も重要であ る，なぜならば，製品の使用感を制御できれば，それを使用 する生活者の気持ちまでも変えることのできる効果 · 効能 とは異なった付加価值に繋がるからである。通常, 生活者 は製品の有用性を評価する際, 外観や触感, におい, 色調, 味, 使用性などを簡単な官能評価によって判断したり, 自分の 嗜好やイメージに合っているかどうかで評価する。例えば,

ライオン株式会社 生活者行動研究所

T 132-0035 東京都江戸川区平井 7-2-1

Tel: (03) 3616-4689, Fax: (03) 3616-6913, E-mail: yamasan@lion.co.jp
クリームや泡状化粧料などの「のび」や「こし」 ${ }^{1-5)}$, シャン プー時やリンス後の毛髪の風合い ${ }^{6-8)}$ などの人間の感覚的な 判断が該当する.

一方, 製造・品質管理の視点から見ると, 製造ロットご とに規格内の外観や粘度を得ることや，これらの性状，物性 值を一定期間維持することが重要な課題となってくる. し かしながら, 熱力学的に不安定な $\mathrm{O} / \mathrm{W}$ エマルションのよう に，同一原料を使用しても，製造時の温度や攪汼条件によっ て微妙に粘度が異なったり, 時間経過とともに粘度変化す ることが多い

これまで感性にもとづく官能評価や品質管理のための物 性制御を客観的に評価するため, 多くの物理化学的手法が提 案されてきた。その中で, 1960 年代にレオロジー的なアプ リーチを用いた化粧品の使用感に関する研究が Sherman $^{9)}$ Barry $^{10)}$ らによって盛んに行われた，その後，1990年代後半 から再び脚光を浴び，研究報告例が増加している。この背 景には, 測定機器の革新, すなわち, トルク制御技術・分 
解能が格段に向上したこと，およびコンピューターによる 複雑，かつ大量のデー夕処理が容易になり，誰でも簡単に 測定や解析ができるようになったためである。また製品の 品質の向上とともに, より生活者が使用感触の重要性を認 識してきたことなども挙げられる.

著者ら ${ }^{11-17)}$ も応力制御型レオメーターを用いて, 香粧品 や化粧品用基剤のレオロジー挙動に関する研究を実施して きた。 これは基剤のレオロジー挙動と内部構造との関係を 定量的に把握し，最終的には製品の製造時から生活者が使 い切るまでの期間, 安定した品質を確保する物性制御技術 に役立てるためである.

本稿では香粧品や化粧品の基剤として利用されるカチオ ン界面活性剤/高級アルコール / 水系の分子集合体を題材に, 時間経過に伴う内部構造の相転移とレオロジー挙動との関 係を中心に述べる。

\section{2. カチオン界面活性剤 / 高級アルコール / 水系分子 集合体の内部構造}

モノアルキル型カチオン界面活性剤は高級アルコールと 特定の比率で混合すると, 水中で $\alpha$ 型の高級アルコールの 結晶構造に近い六方晶形の配列をとって秩序化して系の粘 度が増大する. ${ }^{18)}$ この増粘挙動は, カチオン界面活性剤や高 級アルコールのアルキル鎖長やモル比によって大きく変化 するが，たとえ同一の成分・組成であっても，調製する温 度を変化させると諸物性が顕著に変化する。例えば, Table I に示すように, アルキル鎖長が 16 同士のモノアルキル型カ チオン界面活性剤 $(\mathrm{C} 16 \mathrm{CA})$ と高級アルコール $(\mathrm{C} 16 \mathrm{OH})$ を $1 / 3$ のモル比でゲル液晶相転移温度 (Tc) より高温で調製すると, 乳白色の粘稠なクリームが生成する。これを Cryo-SEM で観 察すると, 数 $\mu \mathrm{m}$ 程度のマルチラメラベシクル粒子が数珠状 に繋がった状態が観察される。一方, 室温付近で混合すると, 外観色はやや透けた薄灰色のゲルが生成する. 同じく CryoSEM で観察すると, 今度は層状のラメラ構造が観察される. ${ }^{14)}$

構造内部に捕捉されている水分量は, 熱重量測定 $(\mathrm{Tg})$ の 結果から, 高温調製品が $30 \%$ と室温調製品に比べて少ない. 言い換えると，系中の自由水が多いことを意味している。ま

Table I. Physicochemical properties of the self-assembly.

\begin{tabular}{|c|c|c|}
\hline $\begin{array}{l}\text { Preparation } \\
\text { temperature }\end{array}$ & Prepared at $75^{\circ} \mathrm{C}$ & $\begin{array}{c}\text { Prepared at } \\
\text { room temperature }\end{array}$ \\
\hline Appearance & Creamy white & Semitranslucent \\
\hline \multirow[t]{2}{*}{$\begin{array}{l}\text { Electromicrograph } \\
\text { for assembly }\end{array}$} & 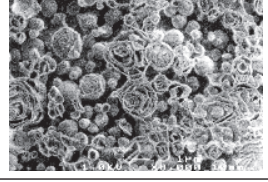 & 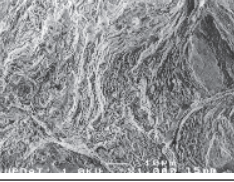 \\
\hline & Multilamellar vesicle & Lamellae \\
\hline $\begin{array}{c}\text { Texure of } \\
\text { immediately after } \\
\text { preparation }\end{array}$ & Viscous liquid & Gel \\
\hline Melting point $\left({ }^{\circ} \mathrm{C}\right)$ & 69 & 67 \\
\hline $\begin{array}{c}\text { Interlamellar } \\
\text { water content } \\
(w t \%)\end{array}$ & 30 & 46 \\
\hline
\end{tabular}

た，ゲル液晶相転移温度も捕捉水分量の影響を受けて，捕捉 水分量の少ない高温調製品のほうが $2{ }^{\circ} \mathrm{C}$ 程度高い值を示した.

マルチラベラベシクルの粒子を有する高温調製品は，短 時間で見れば安定であるが，長時間経過するとベシクル粒子 内の水分量が徐々に増加し, 球状を維持できなくなって, 最 終的には開放的なラメラ構造へと相転移することもわかっ ている.13,16)

以降, カチオン界面活性剂と高級アルコールのモル比を $1 / 2$ に固定し, $\operatorname{Tg}$ 以上の高温で調製した試料の相転移に伴う レオロジー挙動を述べる。なおレオロジー測定はすべて室 温で実施した。

\section{3. カチオン界面活性剤 / 高級アルコール / 水系分子 集合体の流動特性 ${ }^{11)}$}

製品開発者が行うレオロジー測定のうち，最も簡便で汎 用される方法は流動特性である。これは剪断速度（剪断応 力）を連続的に上昇,下降させたときの剪断応力（剪断速度） の過渡応答を観測する方法である。

Fig. 1 に高温調製品（C16CA/C16OH=1/2）を室温に30日 保管し, 剪断応力制御モードで測定した流動曲線を示す. Fig. 1(a)，および Fig. 1(b) はそれぞれ，剪断応力 $\sigma$-剪断速 度 $\mathrm{d} \gamma / \mathrm{dt}$ 曲線，見掛けの粘度 $\eta_{\mathrm{a}}$ - 剪断速度 $\mathrm{d} \gamma / \mathrm{dt}$ 曲線である. 両曲線とも剪断応力を上昇 $\rightarrow 下$ 降させると, 上昇曲線と下 降曲線間に差のあるヒステレシスループが生じ, 上昇曲線
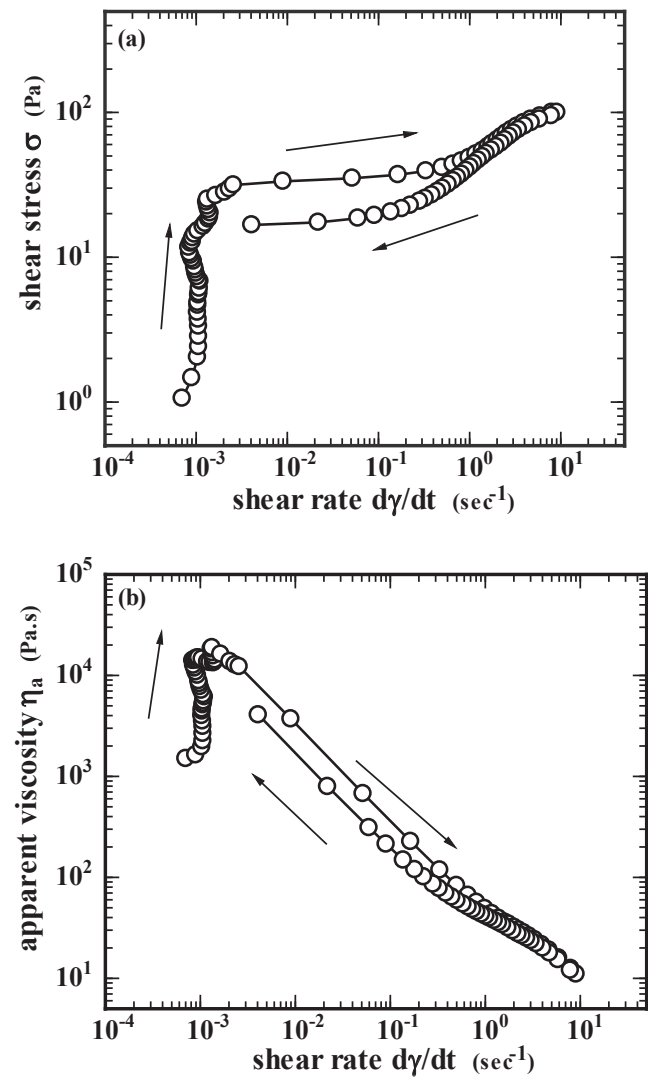

Fig. 1. Flow curves of the self-assembly after storage for 30 days. (a) shear stress s vs. shear rate $\mathrm{d} \gamma / \mathrm{dt}$,

(b) apparent viscosity $\eta_{\mathrm{a}}$ vs. shear rate $\mathrm{d} \gamma / \mathrm{dt}$. 
中の剪断応力によって変形，または破壊された系の構造は，

下降曲線中に復元しないことがわかる。

また Fig. 1(a)の上昇曲線において, 勾配がゼロに近い平坦 な領域が出現しており, これは系の流動が始まる降伏領域に 相当する。一方, Fig. 1(b) をみると, 降伏領域以下の低剪断 速度領域では, $\mathrm{d} \gamma / \mathrm{dt}$ の増加とともに $\eta_{\mathrm{a}}$ も増加するといった shear thickening 様の挙動が見られる。しかしながら, 降伏領 域以下で shear thickening 様の流動が生じるとは考えにくく,

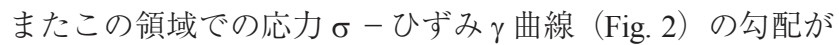
1 の比例関係にあることから，流動が生じているというより も弾性的な変形が起きていると考えたほうがよい.

すなわち, 低剪断応力領域では弾性的な変形が生じ, 応 力が増加して変形が耐え切れなくなり, 降伏領域を経由し て流動が生じるものと思われる。

また Fig. 1(b) の上昇曲線から求めた粘度の極大值 $\eta_{\max }$ の 経時変化を見ると, 試料調製後 1-3 日までは顕著に増加し, それ以降は緩慢な増加に転じている (Fig. 3)。この粘度変化 は系の内部構造のマクロな経時変化と対応しており, 試料 調製後 1-3 日までの粘度増加はベシクル粒子の凝集による網 目構造形成によるもので, それ以降の緩慢な粘度増加は閉 じた構造から開放的なラメラ構造への相転移に対応してい ると思われる。

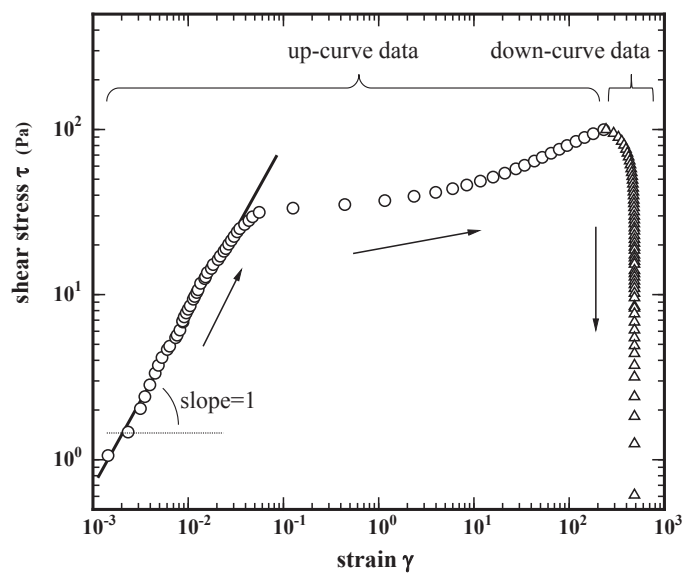

Fig. 2. Relationship between shear stress $\sigma$ and strain $\gamma$ of the selfassembly after storage for 30 days.

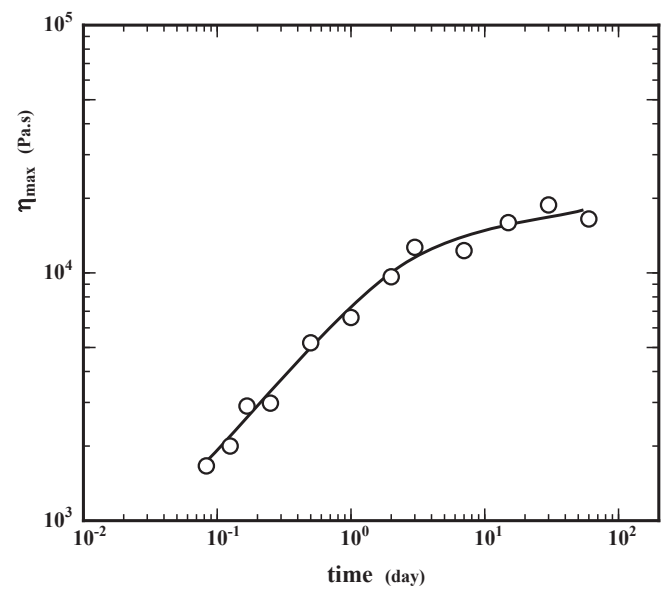

Fig. 3. Change in the maximum apparent viscosity $\eta_{\max }$ with storage time.

\section{4. カチオン界面活性剤 / 高級アルコール / 水系分子 集合体の定常流動 ${ }^{199}$}

定常流動測定は，一定の剪断速度（剪断応力）に対する 応答の時間変化を観測する方法であり, 分散系では流動中 に系の構造変化が生じ，レオロジー特性が変化する場合が 多い. 多くの場合, この種の構造変化は分散粒子の分散や 凝集状態の変化と関連している.

Fig. 4 に高温調製品（C16CA/C16OH=1/2）を室温に 30 日 保管したときの剪断応力制御モードで測定した定常流動曲 線を示す. 剪断応力 $\sigma$ が $1 \mathrm{~Pa}$ の場合, 測定開始直後に見掛 けの粘度 $\eta_{\mathrm{a}}$ が増加し，その後ほぼ一定值に達する。のが $30 \mathrm{~Pa} ， 50 \mathrm{~Pa}$ の場合には，いったん $\eta_{\mathrm{a}}$ は低下し一定值に達す る.100 秒以降の $\eta_{\mathrm{a}}$ が一定值を示す領域では, 剪断応力印加 による系の内部構造破壊と分散粒子の再凝集による構造形 成が釣り合って見掛け上平衡（定常）状態といえる.

平衡状態における応答のデータから平衡流動曲線を求め ると, Fig. 5 のようにプロットでき, 式 (1)のCross の式 ${ }^{20)}$ に比較的適合する。

$$
\sigma=\eta_{\infty} \cdot D+\frac{\left(\eta_{0}-\eta_{\infty}\right) \cdot D}{\left(1+\alpha D^{m}\right)}
$$

ここで $\eta_{\infty}, \eta_{0}$ はそれぞれ高剪断, 低剪断速度領域での粘度,

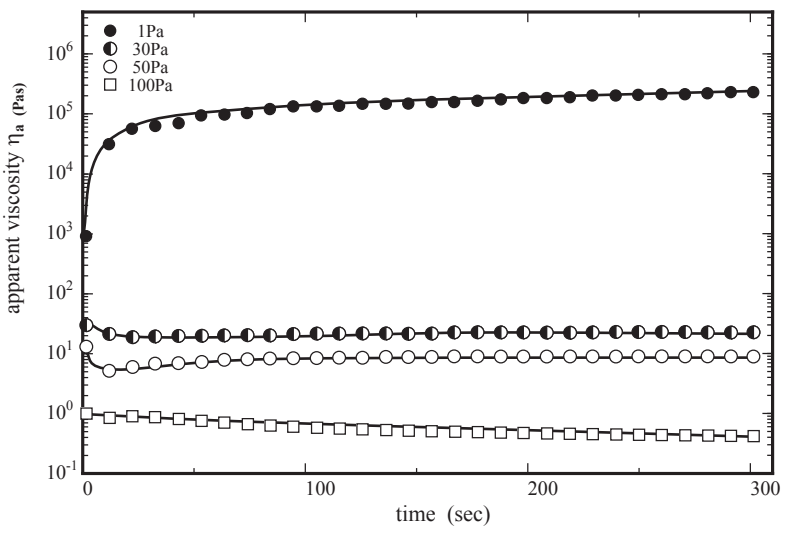

Fig. 4. Constant shear stress test of the self-assembly after storage for 30 days.

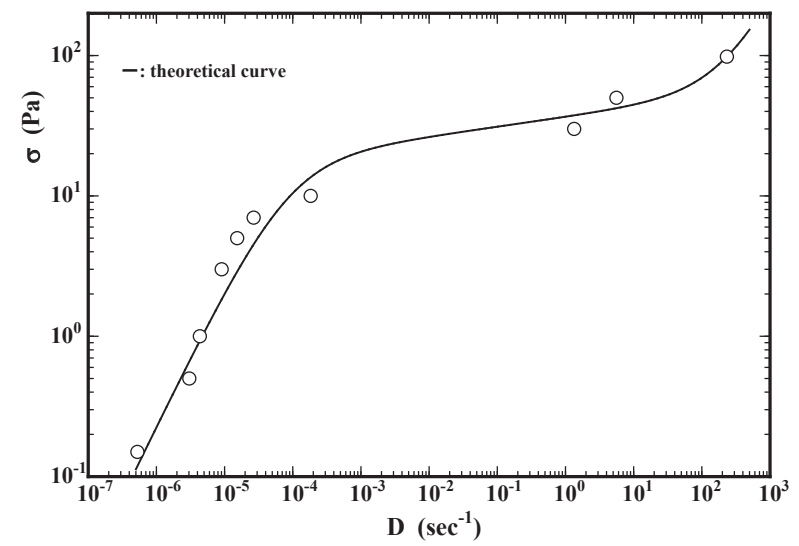

Fig. 5. Example of the applicability of the Cross equation of the selfassembly after storage for 30 days. 
$\mathrm{D}$ は剪断速度， $\alpha$, および $\mathrm{m}$ は定数である.

式 (1) を粘度式に変換すると，

$$
\eta=\eta_{\infty}+\frac{\left(\eta_{0}-\eta_{\infty}\right)}{\left(1+\alpha D^{m}\right)}
$$

と表され, 剪断応力制御のほか, 剪断速度制御, および下 記のクリープ測定で算出したニュートン粘性率 $\left(\eta_{0}\right)$ を, 剪 断速度に対してプロットすると, Fig. 6 に示すように, 広 範囲の剪断速度領域での粘度挙動を把握することができる. 室温 30 日保管品の場合, $\eta_{\infty}=1.935 \times 10^{-1} \mathrm{~Pa} \cdot \mathrm{s}, \eta_{0}=2.275 \times$ $10^{5} \mathrm{~Pa} \cdot \mathrm{s}(\mathrm{r}=0.992)$ となり, 平衡状態における高剪断, および 低剪断速度領域での粘度が推定できる。

\section{5. カチオン界面活性剤 / 高級アルコール / 水系分子 集合体のクリープ測定 ${ }^{12)}$}

クリープ測定は, 試料に一定の応力 $\sigma$ を印加したとき試 料のひずみ (変位) $\gamma$ を測定するもので, Fig. 7 に高温調製 品 $(\mathrm{C} 16 \mathrm{CA} / \mathrm{C} 16 \mathrm{OH}=1 / 2$, 室温保管 30 日）の測定結果を図示 した．試料に応力 $\sigma$ を $15 \mathrm{~Pa}$ の範囲で加えると, $\gamma$ はい ずれも瞬時に増大し，その後直線的に増加する．印加した 応力が大きいほど長時間側での直線の勾配が大きい.

一般にクリープ曲線から解析される力学モデルは, 弾性 要素を表すスプリングと粘性要素を表すダッシュポットが 並列結合（Voigt モデル）し，これが多数直列結合した模型 で表される。このモデルは式（3）表せる.

$$
\gamma(\mathrm{t})=\sigma \sum_{\mathrm{i}=1}^{\mathrm{n}} \frac{1}{\mathrm{G}}\left(1-\mathrm{e}^{-\mathrm{t} / \tau_{\mathrm{i}}}\right)
$$

ここで $\gamma(\mathrm{t})$ は時間 $\mathrm{t}$ における試料のひずみ， $\sigma$ は印加した応 力, $\mathrm{G}_{\mathrm{i}}$ および $\tau_{\mathrm{i}}$ は, それぞれ $\mathrm{i}$ 番目の Voigt モデルの弾性率, 遅延時間（= $\eta_{\mathrm{i}} / \mathrm{G}_{\mathrm{i}}, \quad \eta_{\mathrm{i}}$ は $\mathrm{i}$ 番目の Voigt モデルの粘性率）を 表している．また遅延時間 てがゼロ,および無限大近傍では, それぞれダッシュポットとスプリングが退化したモデルに なるため, これらの極限状態を加味すると式 (3) は式 (4)の ように表記できる。

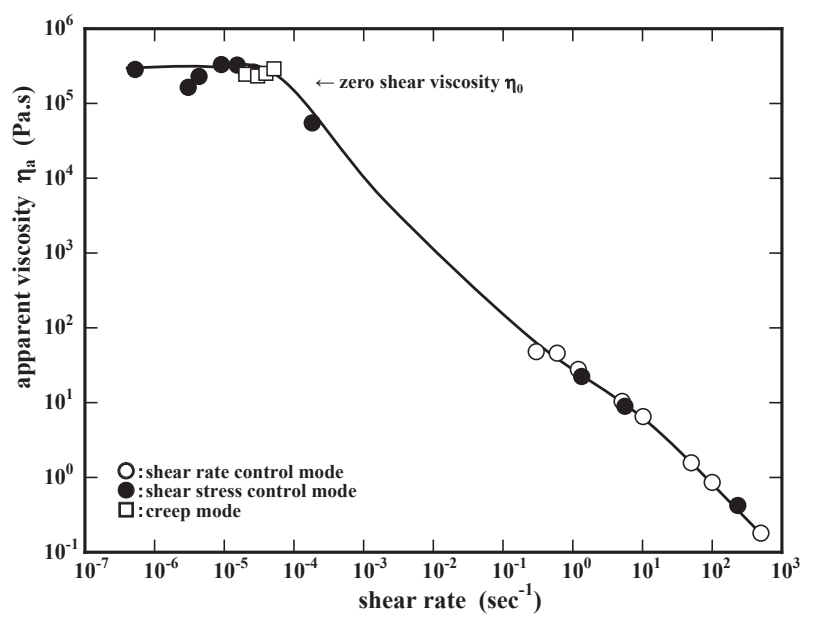

Fig. 6. Constant flow curves of the self-assembly after storage for 30 days.

$$
\gamma(\mathrm{t})=\frac{\sigma}{\mathrm{G}_{0}}+\sigma \sum_{\mathrm{i}=1}^{\mathrm{n}} \frac{1}{\mathrm{G}}\left(1-\mathrm{e}^{-\mathrm{t} / \mathrm{\tau}_{\mathrm{i}}}\right)+\frac{\sigma}{\eta_{0}} \mathrm{t}
$$

式中の $\mathrm{G}_{0}$ は瞬間弾性率 (残留弾性率), $\eta_{0}$ はニュートン粘 性率 (残留粘度) を表している。

式 (4)で表されるモデル中の Voigt モデル数は理論的には 無限大であるが, Inokuchi ${ }^{21)}$ の方法に準拠し, 逐次残差法に よりVoigt モデルの各要素を算出した。その結果, 基剤の力 学モデルは Fig. 8 に示すように, 1 組の Maxwell モデルと 2 組の Voigt モデルが直列した 6 要素モデルで十分に表すこと ができた。

次に経時に対するこれらのモデル要素の変化を Fig. 9, お よび Fig. 10 に示す。瞬間弾性率 $\mathrm{G}_{0}$, およびニュートン粘性 率 $\eta_{0}$ は調整直後から $1 \sim 3$ 日まで比較的急激に増加し, そ の後はほぼ一定值を示した。また長時間側に遅延時間を有 する Voigt モデル要素 $\left(G_{1}, \eta_{1}\right)$ も同様の変化を示した。一方, 短時間側に遅延時間を有するVoigt モデル要素 $\left(G_{2}, \eta_{2}\right)$ は, 調製後 1 ～ 3 日まではほとんど変化しないが，それ以降増 加するといった異なった挙動を示した.

これらのモデル要素の経時変化も流動特性から求めた粘度 の極大值 $\eta_{\max }$ と同様に, ベシクル粒子の凝集による網目構造 形成と, ラメラ構造への相転移に対応しているものと推察で きる。すすおち，瞬間弾性率 $\mathrm{G}_{0}$, ニュートン粘性率 $\eta_{0}$, お

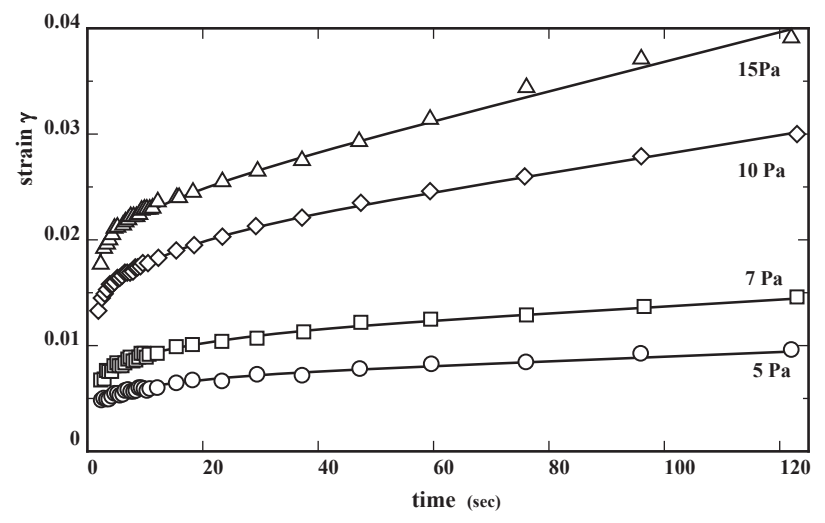

Fig. 7. Creep curves of the self-assembly after storage for 30 days.

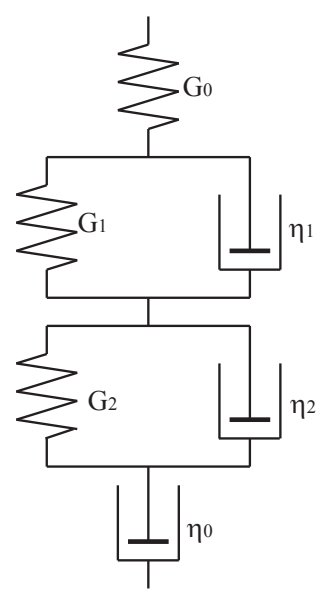

Fig. 8. Mechanical model for the self-assembly. 
よび長時間側に遅延時間を有するVoigt モデル要素 $\left(\mathrm{G}_{1}, \eta_{1}\right)$ は, ベシクル粒子による凝集構造形成を, 一方, 短時間側に 遅延時間を有するVoigt モデル要素 $\left(\mathrm{G}_{2}, \eta_{2}\right)$ はベシルク粒 子のラメラ構造への相転移に関連していると考えられる.

\section{6. カチオン界面活性剤 / 高級アルコール / 水系分子 集合体の動的粘弾性}

\section{1 動的粘弾性のひずみ依存性}

Fig. 11 は周波数 $\omega$ を $6.28 \mathrm{rad} / \mathrm{sec}$ に固定し応力 $\sigma$ を印加し たときの高温調製品 $(\mathrm{C} 16 \mathrm{CA} / \mathrm{C} 16 \mathrm{OH}=1 / 2)$ の動的弾性率 $G^{\prime}$ (Fig. 11(a)）と損失弾性率 $G^{\prime \prime}$ (Fig. 11(b)）のひずみ $\gamma$ 依存性 の測定結果である。調製 2 時間後の試料の場合では, $\gamma$ が $1 \%$ までは $G^{\prime}$ は約 $1.2 \times 10^{2} \mathrm{~Pa}$ と $\gamma$ に依存しない線形領域で ある. $\gamma$ が $1 \%$ を越えると $G^{\prime}$ が急激に低下し非線形となった。 これは応力 $\sigma$ の増加に伴なって内部構造の流動が生じたた めと考えられる。一方， $G^{\prime \prime}$ の值は $10 \%$ 付近で約 $20 \mathrm{~Pa}$ の極 大值を示すことから，この近傍でゲルからゾルへ転移した ものと推測される。また， $G^{\prime}$ および $G^{\prime \prime}$ は時間とともに増加 する傾向を示すため, 調製品の内部構造の形成が進行して いると推察される.

Fig. 11(a)に扔いて $G^{\prime}$ が線形から非線形領域に移行する地 点のひずみを臨界ひずみ $\gamma_{c}$ とし, 式 (5) から凝集エネルギー $\mathrm{E}_{\mathrm{c}}$ を算出した.22,23)
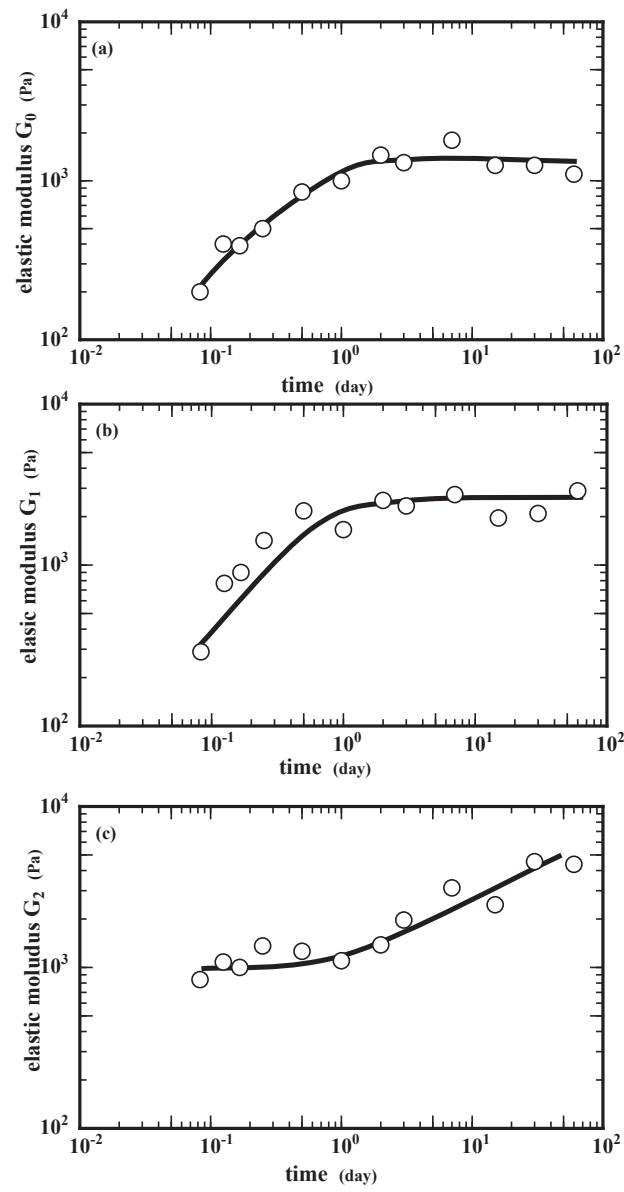

Fig. 9. Change in the elastic moduli of the self-assembly with storage time.
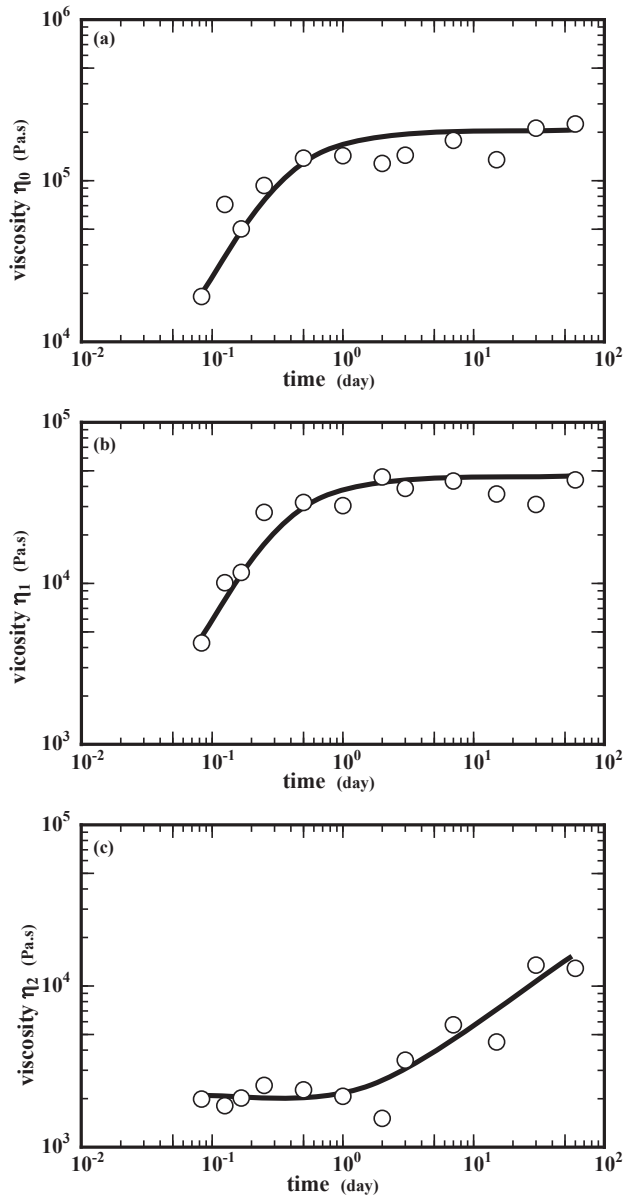

Fig. 10. Change in the viscosity of the self-assembly with storage time.
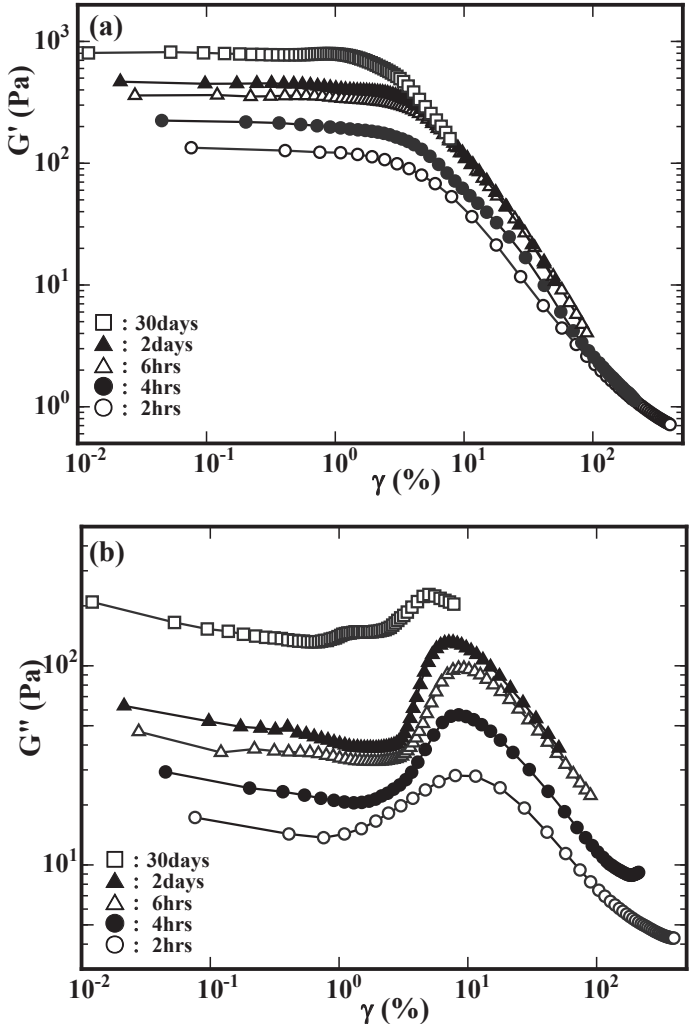

Fig. 11. Plots of $G^{\prime}$ and $G^{\prime \prime}$ against strain. 


$$
\mathrm{E}_{\mathrm{c}}=\int_{0}^{\gamma_{\mathrm{c}}} \sigma \mathrm{d} \gamma
$$

ここで $\sigma$ は試料に加えた応力を意味する。凝集エネルギー $\mathrm{E}_{\mathrm{c}}$ の経時変化を Fig. 12 に示した。試料調製後 2 時間 $0.026 \mathrm{~J} / \mathrm{m}^{3}$ であった $\mathrm{E}_{\mathrm{c}}$ の值はその後急激に増加した後, 1 日以降は緩 慢な増加傾向に転じ 30 日後には $0.25 \mathrm{~J} / \mathrm{m}^{3}$ に達した.

この曲線はFig. 3 に示した $\eta_{\max }$ の経時変化と類似しており, 基剤中のマルチラメラベシクル粒子の凝集に伴う構造形成 は, 調製後 1 日前後までに急速に発達し, その後は長期間 に渡って緩やかに構造形成が進行する相転移に起因するも のと考えられる.

\section{2 動的粘弾性の周波数依存性 ${ }^{13,16)}$}

高温調製品の $G^{\prime}$, および $G^{\prime \prime}$ の周波数 $\omega$ 依存性を Fig. 13 に示す。 $G^{\prime}$ は弾性的な性質を, $G^{\prime \prime}$ は粘性的な性質を表すが, 測定周波数領域では $G^{\prime}>G^{\prime \prime}$ を示し, 調製品は弾性的な性質 が強いと言える. また $G^{\prime}$ は周波数に対して比較的単調に増 加するのに対し， $G^{\prime \prime}$ は $\omega$ に対して 2 つの極大を示した.

また， $G^{\prime} ，$ および $G^{\prime \prime}$ の経時変化をみると， $\omega に$ 対する依 存性は保管期間に関係なく同じ傾向を示しているが, すべ

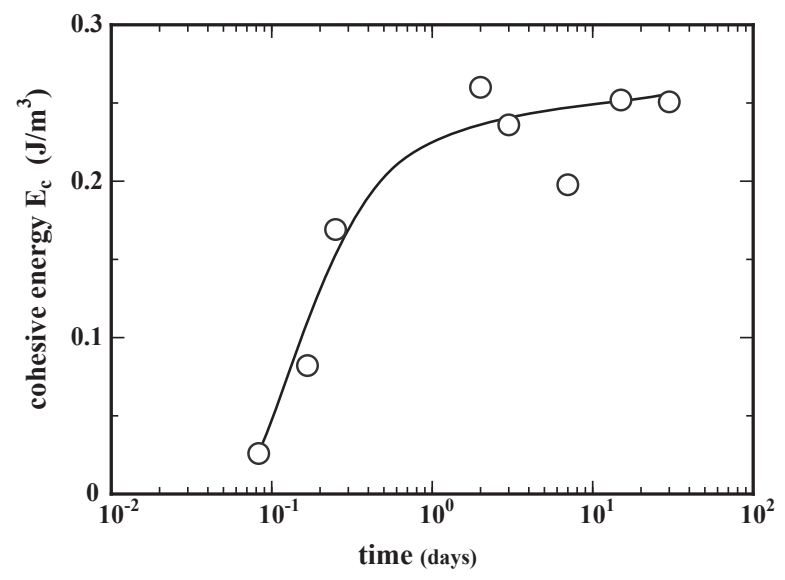

Fig. 12. Change in cohesive energy Ec with storage time.

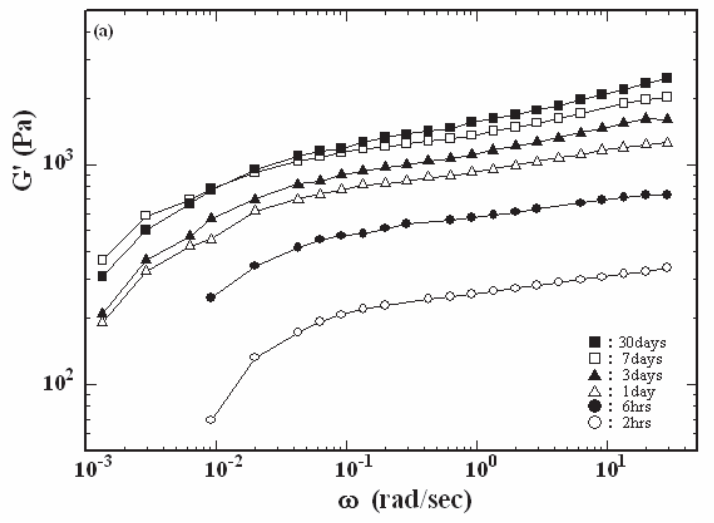

ての測定周波数領域において時間とともに増加し, 歪依存 性の測定結果と同様に構造形成の進行が確認できた。

\subsection{Cole-Cole プロット ${ }^{13,16}$}

Fig. 13 のデータをもとに, Cole-Cole プロットした結果を Fig. 14 に示す。すべての試料は，中心が $G^{\prime}(\omega)$ 軸より下側に ずれた2つの円弧で表された。単一な Maxwell 緩和を示す 臭化セチルトリメチルアンモニウム $(\mathrm{CTAB}) /$ サリチル酸ナト リウム $(\mathrm{NaSal})$ 系のゲル ${ }^{24)}$ は, 円弧の中心が $G^{\prime}(\omega)$ 軸上に存 在する。これは緩和時間に分布のない単一時間を有するた めである。一方，今回測定した基剤は円弧の中心が $G^{\prime}(\omega)$ 軸

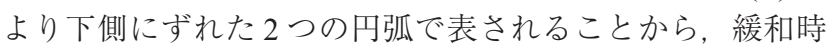
間に分布のある $2 つ の$ Maxwell 様要素からなる緩和機構が 存在すると考えられる.

$G^{\prime \prime}$ の極大值における周波数 $\omega_{\max }$ から式 (6) に従って低周 波数 (長時間) 側, および高周波数（短時間）側の緩和時 間を算出した。

$$
\tau=\frac{1}{\omega_{\max }}
$$

高周波数側，および低周波数側の緩和時間をそれぞれ $\tau_{\mathrm{H}}, \tau_{\mathrm{L}}$ とし，その経時変化を Fig. 15 に示す. 高周波数（短時間） 側の緩和時間 $\tau_{\mathrm{H}}$ は数秒のオーダーであるのに対し，低周波 数（長時間）側の緩和時間 $\tau_{\mathrm{L}}$ は $200 \sim 600$ 秒であった. $\tau_{\mathrm{H}}$ はすべての測定時間において $\tau_{\mathrm{L}}$ よりも小さいことから，高 周波数 (短時間) 側の緩和に関連した構造は, 弾性的な性 質が強いと思われる，さらに $\tau_{\mathrm{H}}$ はわずかに減少傾向にあり， 弾性的な性質が時間とともに増大している．反対に $\tau_{\mathrm{L}}$ は微 増する傾向にあり，粘性的な性質が増大している.

一般に粘弾性液体の緩和に分布がある場合, $\mathrm{p}$ 番目の緩和 モードにおける緩和時間を $\tau_{\mathrm{p}}$, 緩和強度を $\mathrm{G}_{\mathrm{p}}$ とすると, $G^{\prime}$, および $G^{\prime \prime}$ は下式で表される ${ }^{25)}$.

$$
\begin{aligned}
& G^{\prime}(\omega)=\sum_{p} \frac{G_{p} \omega^{2} \tau_{p}{ }^{2}}{1+\omega^{2} \tau_{p}{ }^{2}} \\
& G^{\prime \prime}(\omega)=\sum_{p} \frac{G_{p} \omega \tau_{p}}{1+\omega^{2} \tau_{p}{ }^{2}}
\end{aligned}
$$

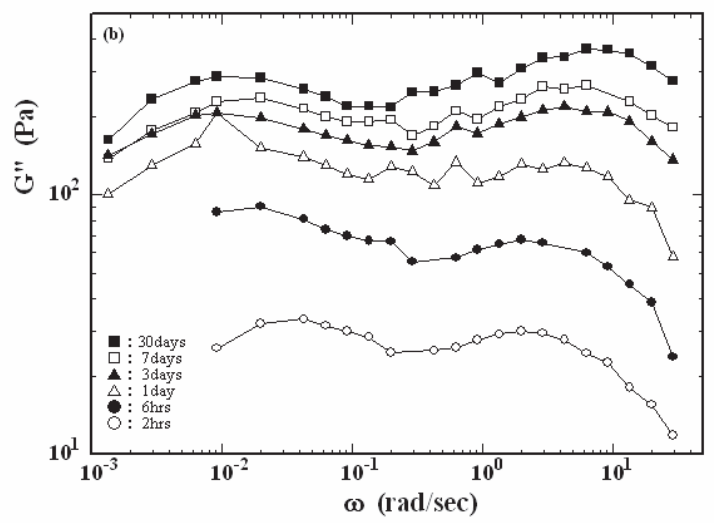

Fig. 13. Plots of $G^{\prime}\left(\right.$ a) and $G^{\prime \prime}$ (b) against frequency. 
また全緩和強度 $\mathrm{I}=\Sigma \mathrm{G}_{\mathrm{p}}$ は $G^{\prime}$, あるいは $G^{\prime \prime}$ のいずれか一方から

$$
\mathrm{I}=\left[\mathrm{G}^{\prime}(\omega)\right]_{\omega=0}^{\omega=\infty}=\frac{2}{\pi} \int_{-\infty}^{\infty} \mathrm{G}^{\prime \prime}(\omega) \mathrm{d} \ln \omega
$$

のように求められる. さらに $\omega \rightarrow 0, \infty の と き, ~ G G^{\prime \prime}$ は 0 に なることから, Cole-Cole プロットの半円と $G^{\prime}$ 軸上の交点の 最大值と最小值の差は全緩和強度 I に相当する。
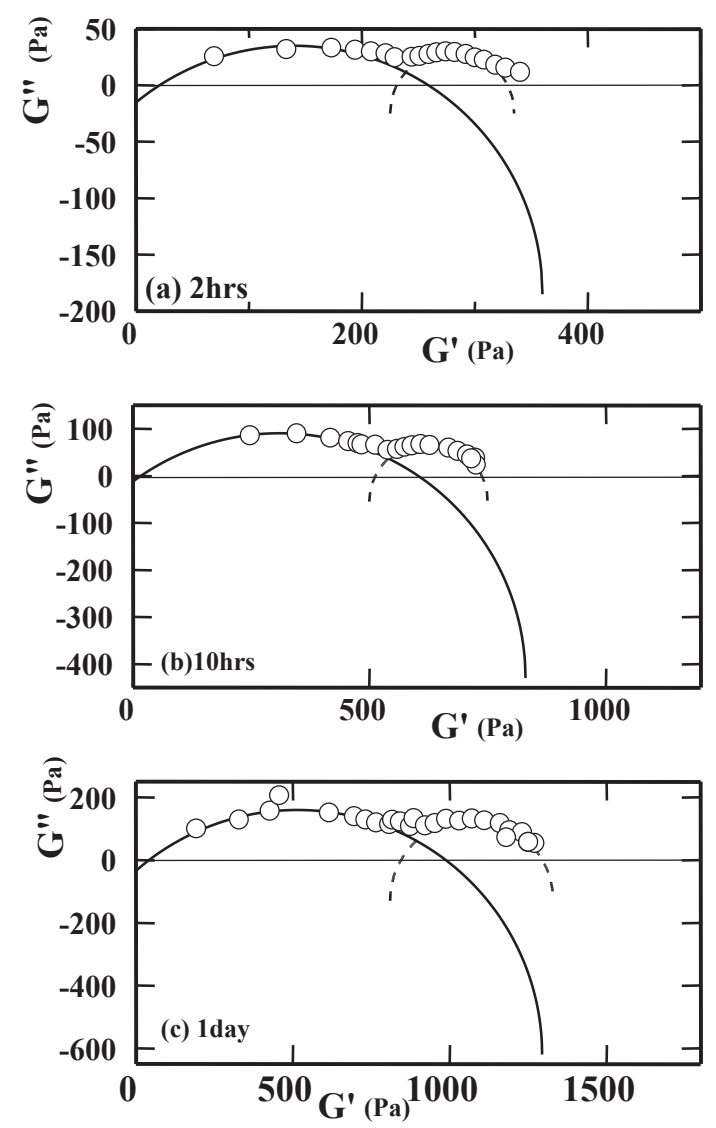

Fig. 14. Cole-Cole plots of the self-assembly.

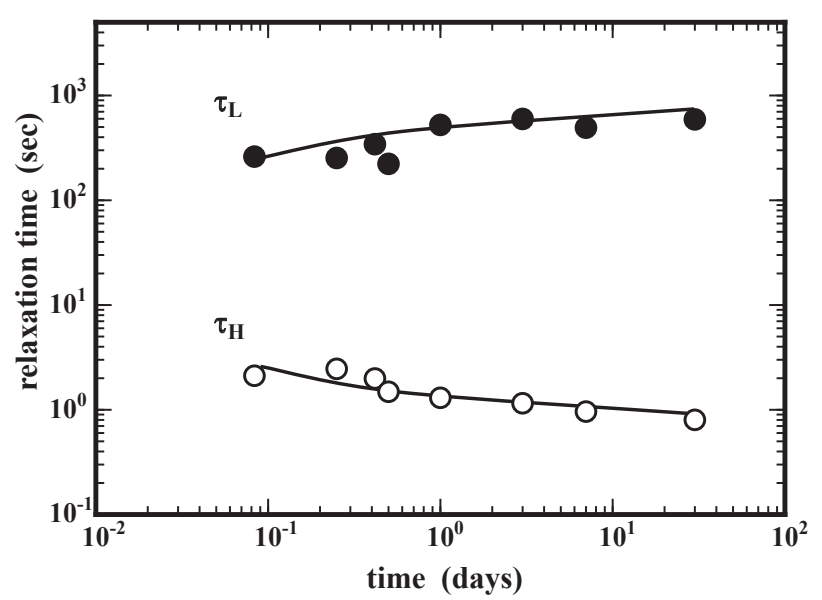

Fig. 15. Change in relaxation time with storage time.
調製品の高周波数側，および低周波数側の全緩和強度を それぞれ $\mathrm{I}_{\mathrm{H}}, \mathrm{I}_{\mathrm{L}}$ とし, 強度比 $\left(\mathrm{I}_{\mathrm{H}} / \mathrm{I}_{\mathrm{L}}\right)$ の経時変化を Fig. 16 に示した，調製直後は 0.5 付近で一定值を示すが，経時 1 日 以降は増加傾向に転じる。調製品の内部構造が時間ととも に, マルチラメラベシクル粒子から層状のラメラ構造へと 相転移する機構を考慮すると, 緩和強度 $\mathrm{I}_{\mathrm{H}}$, および $\mathrm{I}_{\mathrm{L}}$ はそ れぞれ，ラメラ構造とマルチラメラベシクル粒子の凝集構 造の緩和に対応していると結論づけられる.
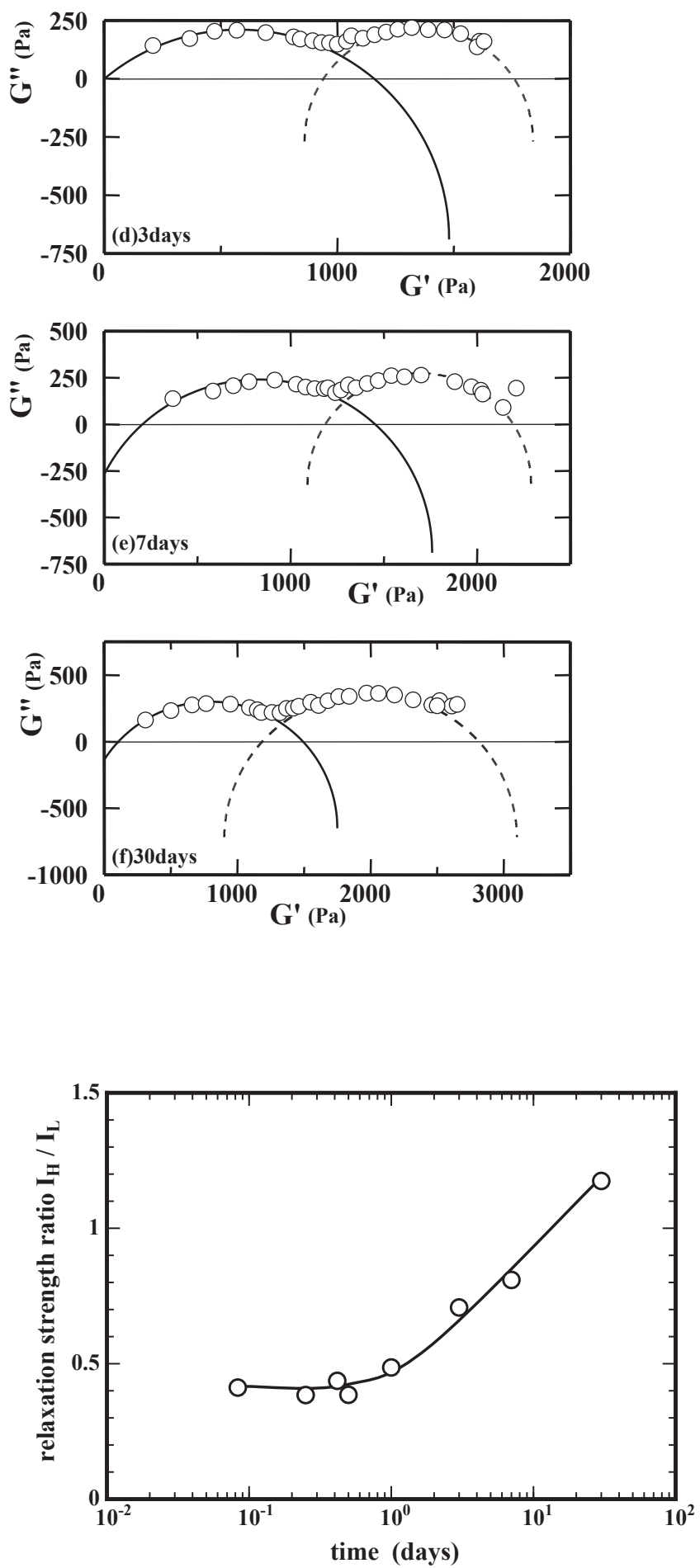

Fig. 16. Change in relaxation strength ratio $\mathrm{I}_{\mathrm{H}} / \mathrm{I}_{\mathrm{L}}$ with storage time. 


\section{7. まとめ}

カチオン界面活性剤 / 高級アルコール / 水系の化粧品基剤 の内部構造とレオロジー挙動に関して, 著者らの研究成果 を中心に報告した。 上述の通り, 化粧品基剤は調製温度や 長期保管により，外観や粘度などの物性が变化する。一定 の品質を長期間維持することは, 製造直後から生活者が使 い切るまでの期間, 同じ使用感触を提供することに繋がり, 重要な研究課題のひとつと捉えることができる. 界面活性 剂の自己組織化による秩序構造は, 分子レベルで見ると同 じとみなすこともできるが，マクロ的には閉じた球状べシ クルや開放的なラメラ構造と形態学的には異なった構造を 形成し，時間に伴った相転移も生じる。このマクロ的な変 化や相違はレオロジー挙動にも影響する。換言すると, レ オロジー挙動を精査すれば，ある程度内部構造の変化を間 接的に捉えることが可能と思われる。

著者らの研究は, 化粧品基剤の時間に対する物性の変化 を, 形態学的な観察とレオロジー挙動の関係から明らかに したが, 今後はいかにして製造直後の状態を長期間安定に 維持できるか, また最終的には生活者が所望する使用感や 感性を数值化して, 自在に操ることのできる技術の確立が 必要と考える。そういう意味では，いまだサイコレオロジー の研究は終着点には達しておらず, 研究課題は残積された ままであり, 今後は香粧品や化粧品の研究に携わる若手研 究員の活躍に期待したい.

\section{REFERENCES}

1) Morita M, Morita K, Hoshiya H, Takada J,Sakon K, Suzuki K, J Soc Cosmet Chem Japan, 24(2), 91 (1990).

2) Yamagata Y, Kiyomiya A, Oguma M, J Soc Cosmet Chem Japan, 26(3), 183 (1992).
3) Boyd JV, J Soc Cosmet Chem, 27, 247 (1976).

4) Suzuki K, Watanabe T, J Texture Studies, 2, 431 (1971).

5) Nakajima N, Fragrance Journal, 37(12), 58 (2009).

6) Miyazawa K, J Soc Cosmet Chem Japan, 29(2), 95 (1995).

7) Suzuki Y, Yahagi K, J Soc Cosmet Chem Japan, 27(1), 11 (1993).

8) Fukuchi Y, Okoshi M, Murotani I, J Soc Cosmet Chem, 40, 251 (1989).

9) Sherman P, J Soc Cosmet Chem, 17, 439 (1966).

10) Barry BW, Saunders GM, J Colloid Int Sci, 34(2), 300 (1970).

11) Yamagata Y, Senna M, Colloids and Surfaces A, 132, 251-256 (1998).

12) Yamagata Y, Senna M, Colloids and Surfaces A, 133, 245-251 (1998).

13) Yamagata $Y$, Senna M, Langmuir, 15(13), 4388 (1999).

14) Yamagata $Y$, Senna M, Langmuir, 15(22), 7461 (1999).

15) Yamagata $Y$, Senna M, Langmuir, 16(15), 6136 (2000).

16) Yamagata Y, Senna M, Nihon Reoroji Gakkaishi, 27(3), 155 (1999).

17) Yamagata Y, Senna M, Nihon Reoroji Gakkaishi, 28(2), 73 (2000).

18) Yamaguchi M, Noda A, Nihon Kagaku Kaishi, 1632 (1987).

19) Yamagata Y, Hyomen, 37(6), 339 (1999).

20) Cross MM, J Colloid Sci, 20, 417 (1965).

21) Inokuchi K, Bull Chem Soc Japan, 28, 453 (1955).

22) Ramsay JDF, J Colloid Interface Sci, 109(2), 441 (1986).

23) Sohm R, Tadros TF, J Colloid Interface Sci, 132(1), 62 (1989).

24) Shikata T, Hirata H, Kotaka T, Langmuir, 3, 1081 (1987).

25) The Society of Rheology, Japan ed., "Koza·Reoroji (Lecture on Rheology)", Chap.2, Kobunshikankokai (1992) (in Japanese). 